Regular Research Article

\title{
A synthesis of the implementation ambivalence of REDD+ in Sub-Saharan Africa and Southeast Asia
}

\author{
Divine O. Appiah ${ }^{1}$, Stephanie E. A. Gbeddy ${ }^{2, *}$ \\ 1 Department of Geography and Rural Development, KNUST, Kumasi, Ghana ; \\ doappiah.cass@knust.edu.gh \\ 2 Department of Geography and Rural Development, KNUST, Kumasi, Ghana \\ * Correspondence author: stephaniegbeddy@gmail.com
}

\begin{abstract}
Reducing emission from deforestation and forest degradation and associated benefits (REDD+), has received much attention as one of the most controversial climate change initiatives, especially by forest fringed community actors in sub-Saharan Africa (SSA) and Southeast Asia, (SEA) who are skeptical of the scheme. The object of this paper is to examine the seeming potential benefits and accompanying risks and challenges of REDD+ on the livelihoods among smallholder farmers in SSA and SEA. The paper espouses the sustainability context of REDD+ projects as pro-poor forest management mechanisms; through the provision of alternative livelihood. This is achieved through critical review and critique of scientific articles, project reports and relevant documents on REDD+ interventions from a worldwide, regional to local scale. The paper identifies projects that seem to solidify claims that REDD+ projects are simply a new form of colonialism; which the West is using to take advantage of vulnerable groups in the South. The paper concludes with the need to actively engage sub-Saharan African and Southeast Asian women in climate change mitigation benefit schemes on account of the expedient role women play in agricultural activities (which may involve deforestation and forest land degradation).
\end{abstract}

Keywords: Community development; Community participation; Gender mainstreaming; REDD-Plus; SubSaharan Africa; Southeast Asia

\section{Introduction}

The importance of taking into consideration the benefits that local communities stand to derive from reducing emissions from deforestation and forest degradation and associated forest carbon stock management (REDD+) schemes, have been recognized by the United Nations programme (UNFCCC, 2010). Despite the fact that the REDD scheme was originally focused on reducing carbon emissions by preventing forest loss, the United Nations Framework Convention on Climate Change Conference of Parties (UNFCCC COP 16) in Cancun, promoted co-benefits (or multiple benefits) and safeguards for REDD+, which entails the reduction in emissions from deforestation and forest degradation with the additional task of conservation, sustainable forests management, for the enhancement of forest carbon stocks in developing countries. This placed the two concepts, high on the international climate change agenda (Lee et al., 2011; Leventon et al., 2014).

The Cancun Agreements sought to stimulate the complete and effective participation of key stakeholders including indigenous communities in REDD+ related actions. This is because; welldesigned benefit sharing mechanisms can enhance livelihoods of local communities as well as strengthen the rights and welfares of indigenous peoples (Lee et al., 2011). The growth of REDD+ has instigated the notion that conservation programs are fairly capable of delivering win-wins by protecting the environment and enhancing community development to reduce poverty (Lawlor et al. 2013). The poverty-environment trap theory postulates that since the environment is a major contributor to a household's production and income, the destruction of the environment, will further aggravate household's poverty scenarios. 
This is because the individual's primary asset would be lost (Lawlor et al., 2013). Globally, there is an estimated 850 million hectares of degraded forests, with deforestation and forest degradation responsible for approximately $17.4 \%$ of annual global carbon dioxide emissions (IPCC, 2007a; UNFCCC, 2007b). Factors accounting for deforestation include; agricultural expansion, unsustainable extraction of forestry products such as fuel wood, forest-residential land use conversions, logging activities, among others (Streck, 2010; Population Action International, 2011; Kissinger et al., 2012). Though carbon dioxide emissions from land use change may seem to be little - between $6 \%$ and $17 \%$ of total carbon dioxide emissions - forests can play a vital role in reducing emissions as well as augmenting the sequestration of carbon in terrestrial reservoirs (Forsell et al., 2016). Thus, interventions aimed at sustainable management of the environment will be beneficial to the rural poor; though this benefit is one targeting poverty stabilization and not necessarily, poverty reduction strategy. However, the introduction of conservation programs such as REDD+ will enhance sustained livelihoods in local populations' property rights and tenure security in their land-based activities (Lawlor et al., 2013).

\subsection{REDD+ Mechanism in Perspective}

Reducing emissions from deforestation and forest degradation (REDD) refers to forest and land based activities which abates forest carbon emissions by minimizing or preventing forest conversion and destruction (Virgilio et al. 2010). The REDD project was implemented due to the evidence that a large percentage of current annual carbon emissions resulted from the loss of tropical forest (Madeira, 2008). Unlike REDD, REDD+ goes beyond deforestation and forest degradation to encompass additional function of ensuring that there is sustainable forest management, including the enhancement of forest carbon stocks. It was further based on the idea that a developing country may receive compensation if it develops a national strategy to reduce its deforestation rate, in proportion to the amount of carbon emissions that are reduced (UNFCCC, 2010). The UN-REDD, was introduced in 2008 to build on the convening role and technical expertise of the United Nations Development Programme (UNDP), the Food and Agriculture Organization of the United Nations (FAO), as well as the United Nations Environment Programme (UNEP) (UN-REDD, 2016).

Policy and economic measures to address these emissions have the tendencies to augment the ability of forests to sequester and store carbon. The concept of carbon sequestration connotes the processes by which green vegetation, through photosynthesis uptake atmospheric carbon dioxide for storage as carbon in biomass and soils (IPCC, 2007b as cited in Virgilio et al., 2010). Since poverty has been recognized as the primary driver of deforestation, adaptation for and mitigation of climate change has in recent times, been addressed in unison with poverty alleviation programmes (FAO, 2010). A community forestry development process initiated in Cameroon in 2001 introduced an environmentally friendly, low-impact approach to forest exploitation, which subsequently led to the locales generating substantial sums of money, in excess of USD $\$ 87,063$ to develop their community for income earning engagements (Minang, 2010).

It is on this account that forest carbon emission mitigation programmes such as REDD+, offer the potential for community development and biodiversity conservation aside its main focus, of climate change mitigation (Virgilio et al., 2010). Commitment from government, corporate entities and individuals in response to reducing carbon dioxide emissions has led to the branding of carbon as a priced environmental commodity on the global marketplace (FAO, 2010). Africa's proportion of the carbon market stands at only 2\% by 2009 (Institute for Security Studies, 2011). Three flexible mechanisms in the Kyoto Protocol allows countries in the heavy emitter countries, particularly in the global north to obviate the adversities of global warming on the south, by investing into emission reduction and carbon sequestration; especially so when the developed countries are seemingly not prepared to commit themselves to specific emissions reduction targets (Virgilio and Marshall, 2009).

An aspect of the Kyoto Protocol, was the Clean Development Mechanism (CDM), created to help some countries meet their emission reduction goals. This mechanism was implemented to allow for emission reduction in the forest sector through afforestation and reforestation programmes. Another focus was to improve forest management with the exclusion of activities 
aimed at REDD; due to skepticism about its credibility as a carbon market scheme (Virgilio and Marshall, 2009).

The sustainable quality and successes of REDD+ initiatives are highly dependent on the participation of local communities, especially smallholder farmers that live in forest fringe areas (Scriven and Malhi, 2012). This review identifies and explains the critical relevance of effective stakeholder engagement and participation in REDD+ project development and implementation. It also details the engagements, especially in relation to the disaggregation of the farmer responses and implementation by gender, an attribute that is crucial in comparative natural resources management.

Thus REDD+ serves as a benefit-sharing system which entails institutional approaches, mechanism and legal instruments for funds distribution and other additional benefits from the programmes. This initiative is vital for providing the necessary inducements to forestall deforestation and forest degradation behaviours, ultimately reducing carbon emissions (Brockhaus et al., 2013). There are, however, some challenges of implementation as critics of the scheme tend to focus on the livelihood dimensions of forest fringe communities. Some of the factors that have and hold further potential to affect the implementation success or otherwise include; security of financial base, human attitudinal responses to the scheme across different scales, access to forest land and related tenure arrangements pertaining to the ownership and organization of forest rights and responsibilities in sub-Sahara Africa (SSA) and Southeast Asia (SEA).

By virtue of reducing deforestation and forest degradation, off-reserve smallholder farmers have viewed the scheme as depriving, of their efforts to expand their agricultural land frontiers by clearing new forest lands for cultivation. In the absence of comprehensive and transparent benefits sharing mechanisms, which invariably characterize some of these schemes in sub-Sahara Africa (SSA) and Southeast Asia (SEA), it has become extremely difficult for the potential implementers, that is, the off-forest reserve farmers to overtly accept the scheme for implementation. It essentially imperative to diagnose the various setbacks and as well as the factors that would impede or promote the successes of REDD+ schemes in the sub-regions, as a way of informing the climate change mitigation components of member countries of these sub-regions' intended nationally determined contributions (INDCs), towards the emission reductions, via the implementation of the REDD+ mechanisms.

The objectives of this paper are to elucidate the various community benefit accruals from existing REDD+ programmes in sub-Saharan Africa and Southeast Asia as well as interrogate some of the implementation ambivalence arriving from human attitudinal responses associated with the implementation of the REDD+ schemes in SSA and SEA. Clarifications have been given concerning the concept of benefit sharing (derived from REDD+ implementation which can be associated with the Payment for Environmental Service (PES) scheme, where tangible benefits (income) are enjoyed by the farmers whilst the ecosystem enjoys the intangible benefits, that is, forest carbon emissions. Details have also been given about the gendered dimension of the REDD+ project in SSA and SEA which is based on the idea that majority of subsistence farmers are women and are thus more likely to be affected by climate change.

\section{Materials and Methods}

\subsection{Profile of Sub-Saharan Africa (SSA)}

Sub-Saharan Africa (SSA), with the total human population of 926 million, politically encompasses forty-eight (48) countries fully or partially located south of the Sahara (PRB, 2013). The region is endowed with vast amount of natural resources ranging from forestry, minerals, energy, and wildlife amongst others. A huge percentage of the region's total population habituates in rural areas where agriculture is the main livelihood activity. Smallholder agriculture is the dominant form of farm organization in this region (FAO, 2009). It is thus no wonder that agricultural income provides the largest source all incomes and offers employment to about $65 \%$ of the region's population. 
High population growth in SSA has predisposed the region to certain threats or challenges. Increasing population implies rising percentage of dependents in the population and thus a heavier burden on the working group. This has heightened the need for families to undertake all forms of activities, both legal and illegal, to acquire income for survival.

Such activities include agriculture, illegal and destructive mining and logging practices which has led to large scale clearing of land as well as caused severe damage to other natural resources (Naoto, 2006). According to Naoto (2006), SSA has one of the highest rate of deforestation; an activity which is believed by some to be caused by poverty.

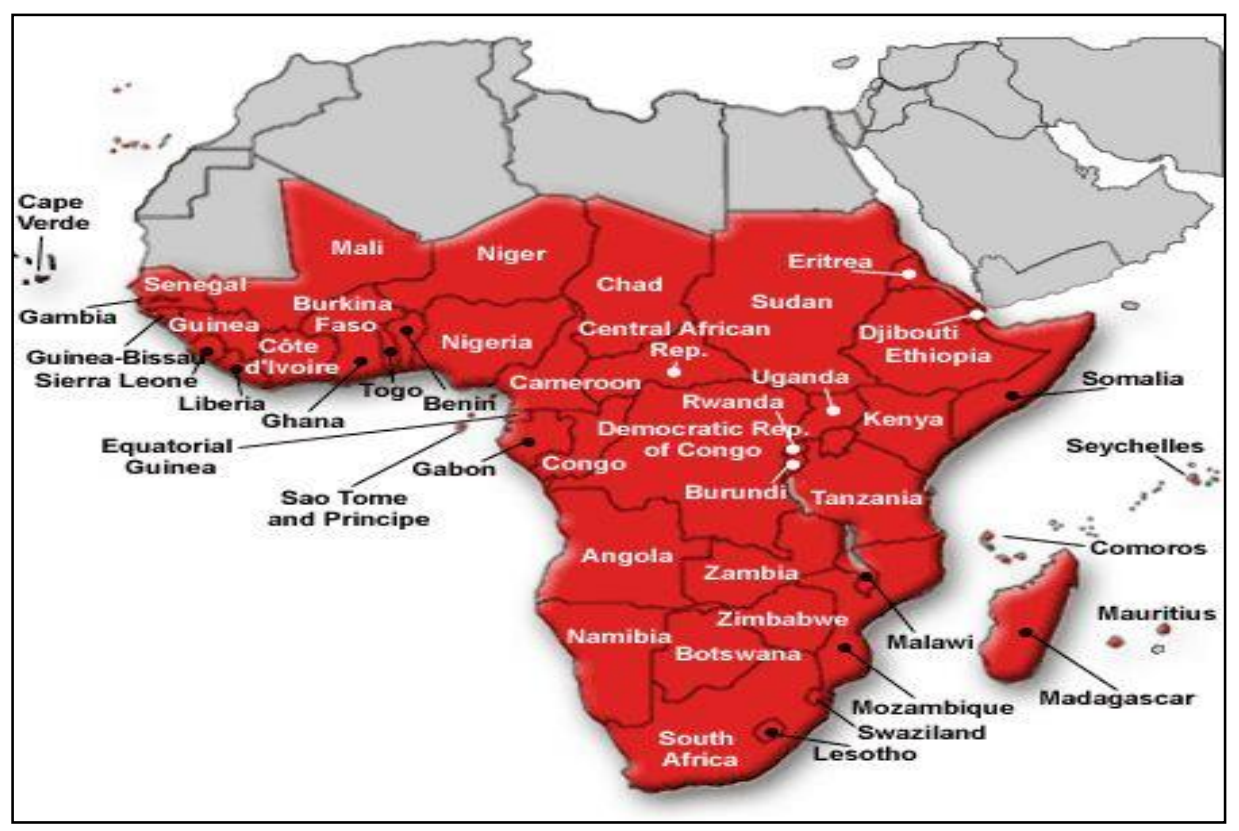

Figure 1: Map of Sub-Saharan Africa

Although Africa has some of the lowest annual greenhouse gas emissions that cause global warming, the impacts of climate change on SSA is very high. This is particularly due to its weak institutions, poor planning and limited finance and information capacities to adapt (WFSE-IUFRO, 2009). Environmental services, such as carbon sequestration, therefore, offer the continent opportunities in the form of the growing carbon markets, by virtue of the continent's rich forest land cover. These forest resources increase the region's potential for REDD+ (aimed at reducing emissions from forests) and its associated benefits (enhanced livelihood for smallholder farmers and protection of biodiversity) (WFSE-IUFRO, 2009). The UN-REDD has played a pivotal role in the development of REDD+ policy framework in many countries in SSA, with countries like Ghana, Cameroon, Tanzania, Benin, Gabon and Zambia (Spratt, 2016; Shanahan et al., 2013).

\subsection{Profile of Southeast Asia (SEA)}

About 300 million people reside in rural parts of Southeast Asia, with around 70 million relying on forests for their livelihoods, fiber, fuel and nutrition (ASEAN Swiss Partnership on Social Forestry and Climate Change, 2015). Despite the fact that forests cover about 50\% (734 million hectares) of Southeast Asia's land area, the region has the highest rate of deforestation and forest degradation in the tropics as a result of destructive activities such as logging (mostly in Papua New Guinea, Indonesia, Myanmar, Malaysia and Cambodia); agriculture - notably oil palm (Wertz-Kanounnikoff and Kongphan-Apirak, 2008; ADB, 2010). Poverty remains prevalent in forested areas due to limited and, or absence of basic services and markets (ADB, 2010). Indonesia has been recognised as one of the top ten emitters of greenhouse gases in the world -with land use change and forestry accounting 
for $65.5 \%$ of its total emissions as at 2013 (USAID, 2017) - largely due to peatland degradation, deforestation and forest fires. The region's vast forest land cover - which serve

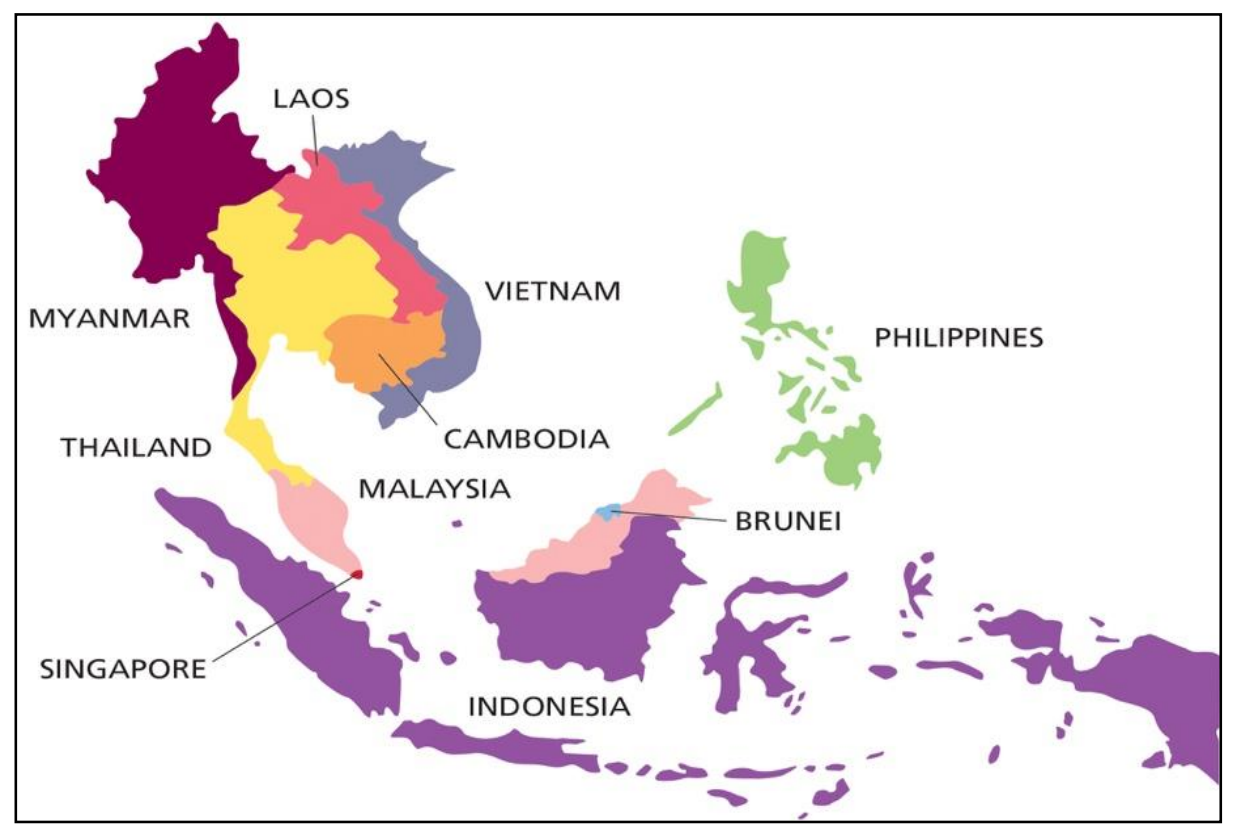

Figure 2: Map of Southeast Asia as significant carbon sinks - offers huge potential to benefit from REDD+ by facilitating $40 \%$ of the scheme's ability to reduce carbon dioxide emissions by 2050 (ADB, 2010).

\subsection{Methods}

The conceptual foundation upon which the discussions were based was on three facts: 1 Forests cover about $50 \%$ of the land cover of Southeast Asia and Africa is home to $25 \%$ of the world's remaining rainforests. 2 Both regions are highly vulnerable to the brunt of climate change. $3 \mathrm{~A}$ large percentage of their population rely on the forests for their livelihoods, ultimately increasing the rate of deforestation (ASEAN, 2015; World Bank Africa, 2017). This presents a firm case for the regions to access funding to promote mitigation and adaptation strategies against climate change (Nakhooda et al., 2011; Kula et al., 2013).

Data attained specifically emanated from project report documents, articles, institutional websites as well as government documents on relevant topical issues with bearings on the subject matter under discussion. The selection of the countries with REDD+ projects was predicated on the principles of acceptability, implementation successes and failures as well as the premium put by each country on the REDD+ mechanism as a potential climate change mitigation measure. A combination of keywords related to REDD+ in sub-Saharan African and Southeast Asia were used to retrieve the relevant works, of which include 'climate change' 'climate impacts' 'adaptations', 'climate change mitigation', 'forest management', 'REDD+', 'community development', 'benefits sharing' and 'gender'. The results of the top 20 literature out of the total of 131 reviewed and referenced works, under various thematic and spatial scopes with special reference to Sub-Saharan Africa and Southeast Asia are displayed in table 1.

Analysis and discussions have laid out the tripartite benefits that serve as community development, enhancement of alternative livelihoods poverty reduction, and gendered ramification, from REDD+ project in SSA and Southeast Asia. 
Table 1: Top 20 relevant references synthesized as the core of the paper

\begin{tabular}{|c|c|c|c|c|}
\hline SN & Thematic area & Author & Scope & Indicators of REDD+ for mitigation successes \\
\hline 1 & REDD+ and Gender & $\begin{array}{l}\text { Nhantumbo and } \\
\text { Chiwona- } \\
\text { Karltun (2012) }\end{array}$ & Global & $\begin{array}{l}\text { 'Deliberate choice' to make payments directly to women } \\
\text { was necessary for the success of the REDD+ programme in } \\
\text { Amazonas, Brazil. }\end{array}$ \\
\hline 2 & $\begin{array}{l}\text { Trends in global } \mathrm{CO}_{2} \\
\text { emissions }\end{array}$ & $\begin{array}{l}\text { Olivier, et al } \\
\text { (2013) }\end{array}$ & Global & $\begin{array}{l}\text { REDD+ involves the storage of carbon that would have } \\
\text { otherwise been emitted into the atmosphere. }\end{array}$ \\
\hline 3 & $\begin{array}{l}\text { National REDD+ } \\
\text { Strategies }\end{array}$ & $\begin{array}{l}\text { Asian } \\
\text { Development } \\
\text { Bank (2010) }\end{array}$ & Asia & $\begin{array}{l}\text { Stakeholder 'partnership' among countries within regions } \\
\text { enablied dialogue on best practices, safeguards and } \\
\text { coordination of REDD+. }\end{array}$ \\
\hline 4 & Governance of forests & $\begin{array}{l}\text { Agrawal et al. } \\
(2008)\end{array}$ & Global & $\begin{array}{l}\text { 'Participation' from local communities in the management } \\
\text { of local forests enhanced the implementation. }\end{array}$ \\
\hline 5 & Forest and People & $\begin{array}{l}\text { Parrotta et al } \\
\text { (2012) }\end{array}$ & Global & $\begin{array}{l}\text { 'Proper management actions' (such as reduced impact } \\
\text { logging (RIL)), promotes REDD+ implementation successes. }\end{array}$ \\
\hline 6 & Kariba REDD+ project & Gogo (2014) & Africa & $\begin{array}{l}\text { The factor of 'investments in training and education' of } \\
\text { farmers is essential for alternative livelihoods trade-off for } \\
\text { REDD+. }\end{array}$ \\
\hline 7 & Gender and REDD+ & $\begin{array}{l}\text { Setyowati } \\
(2012)\end{array}$ & Global & $\begin{array}{l}\text { Women 'capacity-building' in literacy, numeracy, advocacy, } \\
\text { negotiation, community-organisation and skills inures to } \\
\text { the successes of REDD+ projects. }\end{array}$ \\
\hline 8 & REDD & Hall (2014) & Global & $\begin{array}{l}\text { REDD+ must not ignore 'local people's links to, and } \\
\text { knowledge of forests'. }\end{array}$ \\
\hline 9 & $\begin{array}{l}\text { Intergovernmental } \\
\text { Panel on Climate } \\
\text { Change }\end{array}$ & IPCC (2007) & Global & $\begin{array}{l}\text { REDD+ raises 'awareness' and has played a role in the } \\
\text { evolution of many national forestry policies. }\end{array}$ \\
\hline 10 & Forest carbon offsets & Kill (2013) & Global & $\begin{array}{l}\text { 'Local interest' is necessary in order to avoid leakage } \\
\text { (people going elsewhere to harvest trees or grow crops } \\
\text { they could no longer grow in the project area). }\end{array}$ \\
\hline 11 & Drivers of deforestation & $\begin{array}{l}\text { Kissinger et al } \\
(2012)\end{array}$ & Global & $\begin{array}{l}\text { REDD+ has promoted 'sustainable practices' such as } \\
\text { agroforestry and afforestation to address demand for fuel } \\
\text { wood and to increase carbon stocks. }\end{array}$ \\
\hline 12 & Land tenure and REDD+ & $\begin{array}{l}\text { Larson et al } \\
(2013)\end{array}$ & Global & $\begin{array}{l}\text { A defining factor of 'land tenure' is crucial in ensuring the } \\
\text { success of REDD+ projects, in developing countries. }\end{array}$ \\
\hline 13 & REDD+ and Gender & $\begin{array}{l}\text { Livingston } \\
(2015)\end{array}$ & Africa & $\begin{array}{l}\text { 'Women's groups' have enabled a spreading boon of } \\
\text { economic growth in the Kasigau region. }\end{array}$ \\
\hline 14 & $\begin{array}{l}\text { Benefit sharing } \\
\text { mechanisms of REDD+ } \\
\text { projects }\end{array}$ & $\begin{array}{l}\text { Madeira et al } \\
\text { (2012) }\end{array}$ & Africa & $\begin{array}{l}\text { The factor of 'legislation and policy' instruments are } \\
\text { needed to governs land tenure, revenue sharing etc., for } \\
\text { smooth REDD+ implementation. }\end{array}$ \\
\hline 15 & $\begin{array}{l}\text { Carbon markets and } \\
\text { REDD+ }\end{array}$ & Pye (2012) & $\begin{array}{l}\text { Southe } \\
\text { ast Asia }\end{array}$ & $\begin{array}{l}\text { REDD+ has brought to the fore, the need to safeguard the } \\
\text { 'rights of indigenous people' in vulnerable societies. }\end{array}$ \\
\hline 16 & $\begin{array}{l}\text { Livelihood implications } \\
\text { of REDD+ projects }\end{array}$ & $\begin{array}{l}\text { Mutabazi et al } \\
\text { (2014) }\end{array}$ & Africa & $\begin{array}{l}\text { The factor of 'innovation' in terms of REDD+ project } \\
\text { encourages agricultural intensification for enhanced } \\
\text { productivity. }\end{array}$ \\
\hline 17 & Climate change & IPCC (2014) & Global & $\begin{array}{l}\text { Mitigation strategies should be 'integrated into national } \\
\text { development policies'. }\end{array}$ \\
\hline 18 & $\begin{array}{l}\text { Impacts \& adaptations } \\
\text { of climate change in } \\
\text { developing countries. }\end{array}$ & $\begin{array}{l}\text { UNFCCC } \\
\text { (2007a) }\end{array}$ & Global & $\begin{array}{l}\text { Developing 'communication strategies' to make mitigation } \\
\text { strategies accessible to all. }\end{array}$ \\
\hline 19 & $\begin{array}{l}\text { Climate change } \\
\text { mitigation }\end{array}$ & $\begin{array}{l}\text { Virgilio and } \\
\text { Marshall (2009) }\end{array}$ & Global & $\begin{array}{l}\text { Providing 'incentives' for conservation and better forest } \\
\text { management is an ideal way of mitigating climate change. }\end{array}$ \\
\hline 20 & $\begin{array}{l}\text { REDD+ and Local } \\
\text { Democracy }\end{array}$ & Ribot (2011) & Global & $\begin{array}{l}\text { The factor of 'democratic representation of local } \\
\text { populations' at all decision levels on forest governance is a } \\
\text { must for REDD+ to be a tool of justice. }\end{array}$ \\
\hline
\end{tabular}




\section{Results and Contextual Discussions}

\subsection{REDD+ and community development}

One of the main challenges of forest conservation practices is keeping the local populace from undertaking activities that are detrimental to forests but vital for their livelihoods. There seems to be a conflict of interest especially in cases where the people have not been offered sustainable livelihood alternatives which would otherwise restrain them from resource-degrading activities (TFD, 2008). A large proportion of sub-Saharan Africans and Southeast Asians depend heavily on forests for their subsistence, income generation and energy, accounting for the high rates of deforestation in the continent (TFD, 2008; ASFN, 2011).

A study by Madeira et al (2012) indicated that efforts to manage forests sustainably must endeavor to address the root causes of deforestation and forest degradation. According to a report by Funder et al (2009), common causes of deforestation include smallholder agricultural expansion, logging and infrastructure development. Since forests therefore serve as a vital element in the livelihoods of local communities, action must be taken to support a pro-poor forest management mechanism which will consider the needs of the people in its operations.

Many developing countries believe that REDD+ projects have great potential to raise funds for poverty alleviation (Kanninen et al., 2010). Thus, the crucial question is; how can REDD+ benefit the poor? Giving local people's control and utilization power over forest resources deforestation has been the outcome of the over use of the forest resources. Deriving some incentive from benefits sharing of REDD+ is imperative to reduce the deforestation and forest degradation, better and more profitable than cutting down of trees. The REDD+ initiative have potentials to serve as a scheme that provides more benefits both in socioeconomic and ecological sense, than deforestation (Romero et al., 2013). Monies accrued from REDD+ projects are given to participating communities as Payment for Ecosystem Services (PES) in project areas; mostly smallholder farmers to undertake alternative livelihood activities, in a bid to reduce pressure on forests for their sustenance (IUCN, 2011a). This initiative is vital for providing the necessary incentives to change deforestation and forest degradation behaviours, ultimately reducing carbon emissions (Brockhaus et al., 2013; Funder et al., 2009).

Peskett (2011) views benefit sharing as a system that involves the distribution of potentially large financial benefits among all stakeholders linked to minimization of deforestation, degradation and forest regeneration. Aside generating material opportunities for better livelihoods, REDD+ programs have ensured the safety of local population in terms of food and water security. It has also, enhanced land and tree tenure security and improved adaptability to climate change as well as facilitated the enablement of communities to participate in environmental decision making activities (Madeira et al., 2012). Researchers from Sokoine University of Agriculture, Tanzania found that people in the area of Kilosa REDD+ pilot project, preferred alternative forms of compensation such as employment opportunities, infrastructure, and seedlings for woodlots outside protected forest sites, over direct payment (Kajembe et al., 2013).

Emphasis on this was further made by Nabanoga et al. (2012), in their study of poverty impacts of Ongo REDD+ pilot project in Uganda. This study noted that more than $80 \%$ of respondents of study villages preferred indirect sources of payment as compared to $60 \%$ of respondents who agreed to direct payment. This was based on apprehension that direct compensation may be inadequate. One example of the benefits accrued by REDD+ projects is the Mbire council; one of the communities under the Kariba REDD+ project in Kenya. According to the council's chief executive, about 300 farmers receive inputs for conservation farming each year and about 47 boreholes have been sunk to aid improvements in health systems by delivering clean drinking water (Gogo, 2014). Meanwhile, coffee growers within protected forest areas in Sumberjaya, (a sub-district in Western Sumatra, Indonesia) could receive rewards in the form of land tenure as long as they comply with the necessary cultivation and conservation practices (Wertz-Kanounnikoff and Kongphan-Apirak, 2008).

REDD+ projects would inevitably have an impact on how much land a farmer will be able to access since the projects involves conserving large plots of land (Larrazabal et al., 2012). Farmers 
who once harvested on that land will lose their jobs and may be forced to clear forests outside the protected site in a bid to cultivate food crops and this threatens the sustainability of the project (Mutabazi et al., 2014; Larrazabal et al., 2012). There are fears that agricultural restriction in lieu of REDD+ projects, could have adverse implications for food security and other products from agriculture (Dooley and Chapman, 2014). In the Southeast Asian region, it is believed that unsustainable practices and land ownership laws will likely serve as roadblocks to agricultural productivity and lead to the malnourishment of about 60 million in the region (OECD, 2017). A study by Pokorny et al (2013) reports that environmental and local development successes of major forest carbon strategies such as REDD+ are in themselves limited.

It is on this basis, that recent attention has been given to agroforestry as a burgeoning aspect of REDD+ projects especially in sub-Saharan Africa where agricultural activities are predominant and a primary agent of deforestation. Minang et al. (2013), reports that about $40 \%$ of eleven countries in Africa have at least two agroforestry-based REDD+ strategic options. Agroforestry can be described as a climate-smart agriculture intervention that integrates tree cultivation with agricultural production (Minang, 2010; Dooley and Chapman, 2014). It is a very necessary REDD+ scheme which helps to decrease pressure on forests for agricultural land use and fuel; it improves soil fertility; controls soil erosion as well as mitigate carbon dioxide emissions (Murthy et al., 2013). Though this component (agroforestry) sequesters very minimal amount of carbon as compared to protected forests, it helps to provide additional livelihood benefits, food security and save forests that would have otherwise been cut, especially areas outside the protected REDD+ sites (Kill, 2013). Furthermore, Gockowski and Sonwa (2011) have shown that the integration of cacao with timber tree species in the Guinean rainforest of West and Central Africa could have spared 21,000 km2 of forests; reduced emissions of about 1.4 billion tCO2 and also provided income. Portal Limited is an agroforestry business in Ghana that incorporates potential carbon income to earn source of income, thereby making the project a sustainable source of revenue for the local populace (Metzel, 2015).

\subsection{Specific sub-regional cases of REDD+ projects}

Although REDD+ projects have had positive socio-economic outcomes, wrongful management of this intervention can have several adverse impacts on the vulnerable group, that is, the poor. Research in this context has highlighted a number of complaints about various REDD+ projects in Sub-Saharan African and Southeast Asia. According to Shames (2013) and Hall (2014), the unstable price or value of carbon on the carbon markets has played a pivotal role in the unsuitability of REDD+ as a source of finance for forest conservation. Several complaints have been issued by farmers concerning the varied nature of payments and many have resented the fact that carbon prices are determined by global commercial structures that see the former (farmers) as pawns. Studies by Lohmann (2006) and PACJA (2012) as cited in (Lang, 2015), have shown that the low value of carbon on the global markets may not be enough to curb deforestation as locales may find it difficult to subsist on such meagre allowances and may be forced to resort to agricultural and logging activities in other forests, in a process called 'activity shifting' or more popularly, leakage. A research by the center for international forestry research (CIFOR) and centre de coopération internationale en recherche agronomique pour le développement (CIRAD), revealed that the current prices on the carbon market bring limited additional benefits, which threatens sustainable forest management efforts (Baxter, 2015).

Furthermore, the vulnerability of forests to future climatic events, fire and other degrading activities, creates a situation where receipts of payments to locales have become erratic. This notion is emphasized by a group of people representing the 'No REDD in Africa Network'; a group which seeks to put an end to 'carbon colonialism'. According to Nnimmo Bassey, former Executive Director of environmental rights action (ERA), the Nigerian chapter of Friends of the Earth; REDD+ in Africa has emerged as a neocolonialist cliché and a major driver, towards land grabbing (Lang, 2013).

The above opinion can be argued when looking at some current projects, specifically, the much talked about N'hambita Community REDD+ Carbon Project taking place in Mozambique.

\subsubsection{Mozambique}


According to Hall (2014), this REDD+ project in the Sofala region of Mozambique, (originally established in 2002 by Environtrade), represents a bitter case of a REDD+ project gone bad. A study of the project found that farmers had signed contracts that committed them and their children to grow and tend trees for a period of 99 years, albeit the fact that payments would be made for only a seven-year period. Many of the farmers claimed to be oblivious of any such commitments after the seven-year period and assumed that new contracts would be signed thereafter. An examination of a farmer's contract by Via Campesina (the world's largest peasant movement) found that a farmer was to be paid $\$ 128$ per annum over seven years, for tree planting (Hall 2014). It is clear at this point that the farmer is being paid a pittance for protecting trees for such a long period and this will not result, to any improvement in his standard of living. Some farmers mentioned that they had lost the motivation to tend the trees due to late payments and discounts. Many of the farmers attested to the fact that they might cut down the trees after the contracts ended for use, or market as timber or fuelwood and charcoal, as they regarded the wood as a future benefit of the project (Hall 2014). The project was also exposed to financial difficulties due to the decrease in carbon prices. Despite the negative impacts of the project on their livelihoods, some farmers noted that there had been some benefits in relation to fruit trees as food supplements and incomes, as well as the construction of health centres, derived as additional indirect benefit (Hall, 2014).

\subsubsection{Kenya}

Individuals in Binga, one of the four rural communities covering the Kariba REDD+ Project in Kenya have claimed that they have not received any payments and therefore accuse Carbon Green Africa (CGA) of taking advantage of them (Gogo 2014). According to Gogo (2014), CGA, provides inputs to farmers and trains them in alternative livelihoods such as beekeeping and conservation farming. One distraught councilor noted that only 20 farmers out of about 4000 people have benefited from the input supply. The REDD+ programme in this community is characterized by lack of consultation with the locales in that the latter is kept in the dark in matters relating to the amount of credits sold by the project managers and the amount that is due the community from those sales. The CGA chief however retorted that the community gets the least amount of money because it has the least portion of land under the project (Gogo, 2014).

Furthermore, the UNEP-funded Mau forest (REDD+) project in Kenya has been engulfed in serious allegations of human rights abuse. The use of the Mau forest for REDD+ projects was necessitated by the forceful removal of inhabitants from the Mau Forest Complex which led to the displacement of Ogiek original inhabitants, from their traditional abodes. The Mau forest covers 40,000 ha in the Narok District, Rift Valley Region of Kenya (Anaya, 2010). Some of the reasons why the people have failed to embrace this REDD+ programme are that they were not consulted, nor were their consent sought; as negotiations were made behind closed doors. Also they were not given any alternative livelihood options or compensation for their removal despite the fact that they have occupied those lands for centuries (Anaya, 2010). This project ignored an important cultural and social aspect of the indigenous people's relationship with the forest, in this case, their huntergatherer lifestyle. It is a well-known fact that the forest industry in most African countries is weighed down by weak governance, poor land tenure systems and corruption. Hall (2014), stresses that REDD+ projects are likely to exacerbate existing land disputes especially in cases where REDD+ project sites overlap with land rights of forest communities.

\subsubsection{Indonesia}

The Ulu Masen Project in Indonesia was primarily aimed at ensuring the sustainable use of forests and ultimately selling millions of tonnes of carbon on the international voluntary carbon market. Payments were projected to be reach \$26 million over the first five years (WertzKanounnikoff and Kongphan-Apirak, 2008). However, according to some locales who were questioned about the scheme, no benefits nor payments have been attained from the project; and the scheme has failed to sell a single carbon credit even after five years. Also, according to Chris Lang, there are still some people who have no idea what the project is all about (Pye, 2012). 
Another major problem of REDD+ projects is the conflict between indigenous people and the government concerning land ownership and the failure to consult locales on activities relating to the project (Henshaw and Fyneface, 2014). There has been an increasing trend of decentralized forest governance in the tropics, where local communities and users of forest resources control an additional 200 million ha of forests as compared to the 1980s (Agrawal et al., 2008; Sandbrook et al., 2010).

\subsubsection{Cameroon}

The forestry law in Cameroon for instance, enables rural communities to access forest resources in and around their village (Minang, 2010).

Despite this feat however, there continues to be growing disquiets about the adverse outcomes of forest carbon projects like REDD+ schemes that weaken the resource rights of forest-dependent communities, and possible displacement from the fringed community. This is reiterated by Barbier and Tesfaw (2012), who noted that REDD+ initiatives could dispossess and marginalize forest communities especially in cases where tenure security is weak.

\subsubsection{Vietnam}

The nature of the land tenure system in Southeast Asia makes it difficult for the local populace to fully enjoy the benefits of REDD+ scheme. The ignorance of traditional land rights by government policies make schemes such as REDD+ since local landowners have only limited scope to enter such contracts.

According to Wertz-Kanounnikoff and Kongphan-Apirak (2008), the uses to which land is put to in Vietnam is largely determined by the government, and thus, even though households can enter into such contracts, freedom to make land-use decisions is limited. This highly restricted nature of land rights and land use means that the success of any REDD+ project in this region will be dependent on long term government cooperation.

\subsubsection{Nigeria}

According to Rita Osarogiagbon's presentation at the Cross River State forum in Nigeria, the operations of REDD+ projects can be likened to the concept of "a sheep in wolf's clothing" in that, rather than the project reducing emissions as the name depicts, it simply moves emissions around and at times triggers the release of more emissions through leakage. This is usually the case when the rights of forest-dependent communities are undermined (Osarogiagbon, 2011).

In a related instance, residents of Mbe Mountain Cluster Communities have classified REDD+ as another form of land grab, in that, the REDD+ project failed to take consideration of the people's exclusive dependence on the forests for their livelihood. Henshaw and Fyneface (2014), argues that aside $\$ 3000$ made available to them, the community has not benefited from the scheme in any way. Furthermore, the people have been banned from all activities within the protected area with no alternative livelihoods provided. A similar situation in Akampkpa- the Ekuri Cluster and Akpabuyo has engendered a tremendous rise in illegal logging and other criminal activities. Henshaw and Fyneface (2014) further noted that big companies have benefited largely from REDD+ initiatives in terms of large scale land acquisitions at the expense of local communities.

The World Bank has clearly acknowledged that recognizing the rights of indigenous people and forest communities to land resources is fundamental to the success of any REDD+ intervention. However, most REDD+ projects seem to do the opposite as governments seek to forcibly take control of lands owned by local communities (Norton Rose, 2010; Dooley et al., 2011).

\subsubsection{Tanzania}

Many forest-based communities find it difficult to entrust their governments with such projects. This is emphasized by a socioeconomic survey conducted by Kajembe et al (2013) in the Kilosa District REDD+ Project in Tanzania which reported that a few respondents felt that 
compensation was not the appropriate approach to make them stop clearing and using forests because of the lack of trust amongst others (Kajembe et al. 2013).

\subsubsection{Uganda}

In Uganda, a project in the Bukaleba forestry reserve, aimed at offsetting GHG (greenhouse gas) emissions from a coal-fired power plant to be built in Norway is a clear indication of a case of 'Carbolonialism' according to a report by journalist Harald Eraker. The once-off fee of US\$410 coupled with a paltry $\$ 4.10$ per hectare of plantation received by the Ugandan government, was extremely low lease in comparison the the volumes of carbon emission envisaged to emanate from the said coal plant. The project is also responsible for the eviction of about 8,000 people living on the land, dispossessing them of their livelihoods and possibly driving them to degrade lands elsewhere (Lohmann, 2006; Institute for Security Studies, 2011).

It is a truism that communities' engagement in REDD+ plans would help to control leakage since they will be incentivized to maintain healthy forests, thereby ensuring permanence and sustainability of the project (Larrazabal et al., 2012; Hess, 2014; Newton et al., 2015). This opinion is further supported by Chhatre et al (2012), who notes that effective participation at the local level may go a long way to engender or stimulate transparency and accountability in terms of corruption and weak enforcement of the law. Ribot (2011) argues that measures to ensure participation of forest-based communities in REDD+ implementation is not enough and that much attention must be turned towards ensuring local democratic decision-making.

\subsubsection{Papua New Guinea}

The situation in Papua New Guinea make for an interesting case that highlights the consequences of not being aware of one's tenure rights. Landowners who are unaware of their rights are easily exploited (with some signing over carbon rights) by certain carbon project developers - popularly known as 'carbon cowboys' by the media- (Larson et al., 2013). According to Babon et al (2012), one of the 'carbon cowboys' claimed to have made negotiations concerning 90 different carbon deals with various landowners, notwithstanding the absence of a national REDD+ strategy. This scandal brought attention to the dangers of REDD+ for communities and highlighted the need for REDD+ projects to protect the rights of customary landowners.

It is also essential that REDD+ developers make a note of the many ways in which forest communities exchange information and resources in order to ensure proper planning and design of REDD+ systems (ASEAN Swiss Partnership on Social Forestry and Climate Change, 2015). Local communities in Indonesia, Vietnam and Laos have been found to have significant knowledge of forest resources and management, and can measure carbon effectively (ASEAN Swiss Partnership on Social Forestry and Climate Change, 2015). Workshops were held in Kenya and Uganda in 2009 as part of stakeholder consultation process to draw up REDD+ Readiness proposals for the respective countries. A report of the workshop by Julian Sturgeon and Sena Kanyinke, showed that the participants had indeed acquired massive knowledge about the REDD+ process and therefore appreciated that the project had strategic potential not only for carbon sequestration but also for poverty alleviation (IPACC, 2011).

\subsection{Gendered dimension of REDD+}

According to Demetriades and Esplen (2008), UN Women Watch (2009), Brown (2011), Annecke and Koelle (2011), women in rural parts of developing countries are regarded as the most vulnerable to climate change. This is largely, consequential from the pervasively high rates of poverty among women, as compared to men; thereby exacerbating gender inequalities. According to UNDP (1995), women represent $70 \%$ of the poor across the world, and this trend has remained unchanged. Research has found that women comprise about $43 \%$ of the agricultural labour force both globally and in developing countries (Doss, 2014), and produce more than $50 \%$ of the world's food (FAO, 2011). UN-FAO (as cited in Nhantumbo and Chiwona-Karltun, 2012), estimates that women constitute nearly half the agricultural labour force but own only $15 \%$ of the productive land. 
Thus, since women play a role in deforestation and degradation especially through agriculture, it is only expedient that mitigation strategies such as REDD+, mechanisms are gender mainstreamed and integrated into their agroforest resources management, aside their adaptation responses to the impacts of climate change.

Gender mainstreaming is explained by United Nations Economic and Social Council (UN ECOSOC) to mean the co-ordinated mode of political, social economic strategies of identifying men and women as integral part of the design, implementation, monitoring and evaluation of policies in all societal spheres, for equal benefits (Campese, 2011). According to Setyowati (2012), women have a right to access REDD+ benefits and partake in decision making processes on the basis of the vital role they play in forest management of which include tendering of trees on farms, gathering of wild plants for food and medicines, collection of honey and firewood for household consumption and even forest patrolling and monitoring for conservation and preservation of tree species. This is because, men and women use the forests and forest resources differently and may, thus, experience differently, the effects of climate change and REDD+ policies (Sills et al., 2014).

However, international agencies and governments largely underestimate women's contributions to forest management and ignore their needs and perspectives. But it must be noted that attention to REDD+ as a gender- responsive climate mitigation policy has increased considerably over the last decade as women are being placed at the center or heart of climate change policy discourse (Rietbergen-McCracken, 2011; Okali and Naess, 2013). This attention has been largely based on the insecure access to and limited property rights of women over forests and productive land as well as the exclusion of women in decision making processes on climate change; all of which have been recognized as major drawbacks to gender equality in the forestry sector and the implementation success of REDD+ initiatives (Ndobe, 2010; Mwangi et al., 2011, Setyowati, 2012; Okali and Naess, 2013). In the case of Nepal for instance, women's authority over management and use of forest benefits are not recognised reiterating the fact that discrimination against women is not just limited to culture and norms but extends to institutional arrangements (Basik et al., 2012).

Some of the menaces of REDD+ for women according to Gurung et al. (2011), include the displacement from forest lands, the inability of women to receive their fair share of the benefits as well as the frequent exclusion of women from consultations and capacity building workshops. Gurung (2011) further stresses that the lack of integration of gender perspectives into REDD+ implementation will have deleterious effects on the long-term sustainability of REDD+. Studies show that the strong connection of women to natural resources such as forests makes them the most efficient managers of the environment (Adeniji, 2011; Mwangi et al., 2011; Okali et al., 2013). Women in rural areas - as primary forestry users - tend to have unique local knowledge systems that can provide both environmental and social benefits from REDD+ (Setyowati, 2012). Environmental benefits include ecosystem services such as conservation of forest biodiversity, soil nutrient and moisture conservation, water regulation and many others, whist expected social and economic benefits include poverty reduction, improved livelihoods, gender equality and inclusive in decision making and governance (UN-REDD, 2013).

Whilst some countries in Africa have not done much to improve the incorporation of gender perspectives in its REDD+ policies, others like Mozambique, have made considerable attempts at integrating gender in the context of REDD+ implementation. The survey conducted by Micaia foundation, an NGO in Manica included gender-defined information on the causes of deforestation and degradation, in order to identify 'who does what?'; so as to establish policies that will help reduce emissions (Nhantumbo and Chiwona-Karltun, 2012). In similar manner, progress has been recorded in Nepal where community forestry policies were amended in 2009 to ensure that women accounted for $50 \%$ of community forestry executive committees.

In another vein, the country has been actively taking measures to address gender equality and exclusion in the forestry sector (FAO and RECOFTC, 2015). Accessibility to extension services, technological information and innovation, credits and markets have been hindered by low literacy rates among women in SSA, among other factors; all of which limits their ability to undertake activities that support REDD+ (Nhantumbo and Chiwona-Karltun, 2012). Also, the male and state 
dominated nature of tenure rights in SSA, makes it difficult for women to legally own lands and this has negatively affected them when it comes to sharing the benefits of REDD+ initiatives. This is because, in most cases, tenure rights determine who will be eligible for REDD+ benefits. Gender issues in land tenure must, therefore, be addressed in order to ensure sustainable REDD+ outcomes; otherwise women will continually be sidetracked.

In order for women to enjoy the benefits of REDD+, the benefit sharing mechanism used in REDD+ projects must be designed and suited to meet the specific needs of women in a bid to empower them economically and socially (Peskett, 2011). Gender analysis tools were designed to monitor the gender sensitivity of forestry related programmes such as the Community-Based Forest Management Strategy (CBFM) in the Philippines. These tools assess the specific needs of men and women, and the level of participation of stakeholders in all aspects of a project (design, implementation, monitoring and evaluation). The programme has received much accolade from the international community due to its gender-inclusive approach (FAO and RECOFTC, 2015). Poffenberger (2011) recognizes that the problem of making REDD+ payments accessible to women may be surmounted by linking REDD+ funds management to women-centered micro-finance supported activities.

Studies indicate that supporting women-centered groups in REDD+ project sites can help address gender equality, ultimately resulting in the effective functioning and long-term sustainability of forest management enterprises (Agrawal, 2001; CIFOR, 2012; Djoudi et al., 2012; Setyowati, 2012; WOCAN et al., 2013; Sills et al., 2014; Larson et al. ,2015). A case in point is the Kasigau Corridor REDD+ project in Kenya, according to Livingston (2015), which provided sustainable livelihoods for people to the extent that women have been recognized as effecting major changes in the communities whilst protecting forestlands.

According to the report by Livingston (2015), women's groups engage in alternative livelihood activities such as production of arts and crafts like basket weaving, stuffed animals, jewelry and many others; all of which are sold in the United States, via REDD+. Monies from these projects have been used to build water tanks for communities, bought for households, solar lighting and clean cook stoves as well as delivering education for their children. Additional opportunities include the inclusion of women into the Wildlife Works Ranger Corps to protect forests from slash and burn agriculture. Women have also joined the projects' eco-charcoal making team. This is a clear illustration of the consideration of women into the benefit sharing initiative of REDD+ which ultimately empowers them both economically and socially. A report by Wambugu et al (2015) on the other hand, indicated that there was low representation of women in decision making activities relating to the Kasigau REDD+ project.

Studies have also shown that women in forest communities are mostly ignored and restricted when it comes to making decisions concerning forest management (Gurung, 2011; Nhantumbo and Chiwona-Karltun, 2012). Several reasons account for this of which may include the fact that women spend most of their time taking care of their households and are thus disregarded in matters relating to forests whilst men are more mobile and have wide-ranging network (Annecke and Koelle, 2011). Consuelo Espinosa, a Senior Forests and Climate Change Officer of the international union for conservation of nature (IUCN), noted that women are usually marginalized on discussions pertaining to forest management, due to constraints to own forest lands (IUCN, 2010). Women, however, must have equal representation and influence in decision making as men in so as to obviate any adverse impacts of REDD+ on women's livelihoods.

Larson et al (2015), in a study of 20 REDD+ sites across six countries, pointed out that REDD+ projects only focused on the participation of women in numerical terms without considering whether the women feel included and if their participation influenced decisions. This was reiterated by Nhantumbo and Chiwona-Karltun (2012), who opined that women may not have the opportunity to freely express their views due to socio-cultural norms and this may discourage them from engaging in future meetings. In contrast to this, however, a study undertaken by Awono et al (2014), reported that women in REDD+ project sites were actually playing major roles in matters relating to the management of natural resources. According to the report, a considerable number of women in Mount Cameroon had statutory positions in local forest management committees. 
REDD+ initiatives should be formulated to facilitate women's meaningful participation rather than simply inviting them to discussions. Campese (2011), highlights some of the strategies of which include organizing women only meetings to help them prepare for discussions; posting information in places where women congregate; framing information in ways that addresses their interests and rights; providing gender specific training in traditionally male activities as well as forming tasksharing groups in order to offer adequate participatory time for women to discussions without recourse to any overburden.

Countries across sub-Saharan Africa and Southeast Asia have taken into consideration the importance of gender mainstreaming into their respective REDD+ policies and implementation. The launch of the Gender and REDD+ roadmap in Ghana was viewed as a stepping stone towards the enhancement of the participation and contribution of women and other vulnerable groups to the forestry sector (IUCN, 2011b). Key stakeholders (such as gender officers from government ministries, representatives-women and men- from participating communities and women organizations in the forestry sector) were trained to understand the differentiated impacts of climate change on men and women, the different roles of men and women in forestry and what needs to be considered gender-wise for the success of REDD+ initiatives (IUCN 2011b). But many of them still remain gender-blind without much elaboration on what should be practiced (Smith, 2011). Mention can be made of National REDD+ proposals of countries like Kenya, Tanzania and Cambodia which does not mention specific strategies to integrate gender into proposed implementation strategies and fails to address the issue of women's participation in decision making respectively (Smith, 2011; WOCAN ,2011).

\section{Observations and Conclusion}

The arguments in the literature on the social economic benefits of REDD+ thus far, seem to point to a rather negative consequences of the potentials of the scheme in general. However, this paper counter-argues in sync with the views expressed from the positive experiences enumerated from the success stories emanating from the SSA and SEA sub-regions, that indeed REDD+ holds the potential to bring about sustainable community livelihood development. This would be particularly realized, when it is embraced by forest-fringed communities as an integral part of their subsistence livelihood engagements. This is because, the opportunities of an integrated human-ecosystem management from an agroforestry and other forestry programs perspectives hold potentials for climate change mitigation, using possible carbon emissions abatement as well as an adaptation strategy through the generation of alternative incomes from tree crops and carbon credits.

Despite the fact that women are the most vulnerable groups to climate change, measures must be taken to acknowledge the potential of women as effective agents or actors of climate mitigation and adaptation actions this would hold especially so, since they are the core users of natural resources. Thus the skills, roles and knowledge of women should be adequately tapped in considering holistic efforts to manage forest resources in a sustainable manner since the adage that "when the last tree dies, the last man dies" is not far from the reality.

\section{Author Contributions}

Divine Odame conceived of the study, helped in the design of the study, proofread and edited the final text. Stephanie Gbeddy reviewed literature from various sources and drafted the document. Both authors undertook discussions of the key issues raised in the paper.

\section{Conflicts of Interest}

The authors declare that they have no competing interests.

\section{Acknowledgments}

Acknowledgements are due to the Department of Geography and Rural Development (KNUST) for providing us with the opportunity to undertake this research project. 


\section{References}

Adeniji, G. (2011). Women as key players in climate adaptation. Jotoafrika, issue 6

Agrawal, B. (2001). Participatory Exclusions, Community forestry, and Gender: An Analysis for South Asia and a Conceptual framework. World development (29).10, p 1623-1630.

Agrawal, A., A. Chhatre., and Hardin, R. (2008). Changing Governance of the World's Forests. International Forestry Resources and Institutions Program (IFRI) Working Paper \#08I-4

Anaya, J. (2010). Kenya: Alleged eviction of the Ogiek Indigenous peoples from the Mau Forest Complex. Support Project for the United Nations Special Rapporteur on Indigenous Peoples

Annecke, W. and Koelle, B. (2011). Including women in adaptation processes. Indigo Development and Change, jotoafrika issue 6

ASEAN Swiss Partnership on Social Forestry and Climate Change. (2015). Social forestry and climate change in Southeast Asia. CIFOR Research findings and goals. Center for International Forestry Research (CIFOR).

[ASFN] ASEAN Social Forestry Network. (2011). ASEAN-Swiss Partnership on Social Forestry and Climate Change. Program Document 2011-2013. Jakarta, Indonesia.

Asian Development Bank (ADB). (2010). National REDD+ Strategies in Asia and the Pacific: Progress and Challenges. Mandaluyong City, Philippines. p 1- 4.

Awono, A., Somorin, O. A., Atyi, R. E., Levang, P. (2014). Tenure and participation in local REDD+ projects: Insights from southern Cameroon. Environmental Science \& Policy. (35), p 76-84

Babon, A., Mcintyre D., and Sofe, R. (2012). REDD+ politics in the media: A case study from Papua New Guinea. Center for International Forestry Research (CIFOR). Working Paper 97.

Barbier, E.B. and Tesfaw, A. T. (2012). Can REDD+ Save the forest? The Role of Payments and Tenure. Forests, 3, ISSN-1999-4907, P 882-885

Basik, N., Molnar, A. DiPaolo, J. and Qureshi, M. (2012). Leadership for Forest Management: A Summary of the Asian Experience. Rights and Resources Initiative. Jakarta, Indonesia.

Baxter, J. (2015). REDD+ to the rescue of Central Africa's forests? Not yet, study says. CGIAR Research Program on Forests, Trees and Agroforestry. Center for International Forestry Research (CIFOR)

Brockhaus, M., Luttrell, C. Wong, G. Pham, T. T. Dung, L. N. Tjajadi, J. S., Loft L. and Mvondo, S. A. (2013). Comparative Analysis of REDD+ benefit sharing mechanisms for Efficiency, Effectiveness and Equity. Center for International Forestry Research (CIFOR)

Brown, H. C. P. (2011). Gender, climate change and REDD+ in the Congo Basin forests of Central Africa. International Forestry Review Vol.13 (2), p 164-166

Campese, J. (2011). Gender and REDD+ in Tanzania: An overview of key issues. Tanzania Natural Resources Forum

Chhatre, A., Lakhanpal, S. Larson, A. M. Nelson, F. Ojha, H. and Rao, J. (2012). Social safeguards and co-benefits in REDD+: a review of the adjacent possible. Current Opinion in Environmental Sustainability, Elsevier Limited, p 657

CIFOR (2012). Forests, Trees and Agroforests. A Strategy for Gender-Responsive Research and Action. Bogor: CIFOR.

Demetriades, J. and Esplen, E. (2008). The gender dimensions of poverty and climate change adaptation. IDS Bulletin 39(4): 26-31.

Djoudi, H., Brockhaus, M., Brown, H. C. P., \& Bandiaky-Badji, S. (2012). Forests: gender, climate change and women's representation. CIFOR Infobrief, (48).

Dooley, K., Griffith, T., Martone, F., and Ozinga, S. (2011). Smoke and mirrors: A critical assessment of the Forest Carbon Partnership Facility. FERN and Forest Peoples Programme

Dooley, E., and Chapman, S. (2014). Climate-smart agriculture and REDD+ implementation in Kenya, Cambridge Centre for Climate Change Mitigation Research (University of Cambridge)-REDD+ Law Project

Doss, C. (2014). If women hold up half the sky, how much of the world's food do they produce? In Gender and Agriculture: Closing the Knowledge Gap, edited by A.R. Quisumbing, R. MeinzenDick, T. L Raney, A. Croppenstedt, J.A. Behrman, and A. Peterman. Springer, Netherlands. 
FAO. (2011). Women in Agriculture: Closing the gender gap for development. In: The state of food and agriculture. FAO, Rome, Italy.

FAO. (2009). The special challenge for sub-Saharan Africa. High Level Expert Forum-How to Feed the World in 2050. Rome-Italy

FAO. (2010). Impact of the global forest industry on atmospheric greenhouse gases. Food and Agriculture Organization of the United Nations, Rome, Italy. FAO Forestry Paper 159.

FAO and RECOFTC. (2015). Mainstreaming Gender into forest policies in Asia and the Pacific. Food and Agriculture Organization of the United Nations; The Center for People and Forests, p 3-6.

Forsell, N., Turkovska, O., Gusti, M. Obersteiner, M. Elzen, M. and Havlik, P. (2016). Carbon Balance and Management.

Funder, M., Fjalland, J., Ravnborg, H.M., and Egelyng. (2009). Low Carbon Development and Poverty Alleviation: Options for development cooperation in energy, agriculture and forestry. Danish Institute for International Studies (DIIS) Report: Climate Change, Copenhagen, Denmark.

Gockowski, J., Sonwa. D. (2011). Cocoa intensification scenarios and their predicted impacts on CO2 emissions, biodiversity conservation and rural livelihoods in the Guinea rainforest of West Africa. Environ Manage

Gogo, J., (2014), Zimbabwe: Outcry over Kariba REDD+ Project, No REDD in Africa Network

Gurung, J. (2011). Women's exclusion from forestry. In IUCN Arborvitae: Attending to gender. The IUCN Forest Conservation Programme Newsletter, issue 43, p 8-9

Gurung, J., Giri K., Setyowati A. and Lebow, E. (2011). Getting REDD+ Right for women: An analysis of the barriers and opportunities for women's participation in the REDD+ sector in Asia. USAID, Washington DC

Hall, R. (2014). The great REDD gamble: Time to ditch risky REDD for community-based approaches that are effective, ethical and equitable. Friends of the Earth International (FOEI), Amsterdam

Henshaw, K. and Fyneface, D. F. (2014). Seeing REDD: Communities, Forests and Carbon Trading in Nigeria. Social Development Integrated Centre (Social Action)

Hess, J. S., (2014). Is REDD+ the right approach to reducing deforestation in tropical forest countries? Retrieved: August, 23, 2016 from https://climate-exchange.org/2014/02/02/is-redd-theright-approach-to-reducing-deforestation-in-tropical-forest-countries-3/ .

Institute for Security Studies. (2011). Carbon trading in Africa: A critical review. Institute for Security Studies (ISS) No. 184/ ISBN- 978-1-920422-62-2, p 21

Intergovernmental Panel on Climate Change (IPCC). (2007a). Summary for Policymakers. In: Climate Change 2007: Synthesis Report. Contribution of Working Groups I, II and III to the Fourth Assessment Report of the Intergovernmental Panel on Climate Change, [Core Writing Team, Pachauri, R.K. and Reisinger, A. (Eds.)], Geneva, Switzerland.

IPACC. (2011). African Indigenous Peoples and REDD+ Human Rights, equity and forest carbon capture in climate mitigation. Indigenous Peoples of Africa Coordinating Committtee (IPACC)ISBN 978-0-9814477-4-2, p 29

IPCC. (2007b). Climate Change 2007: Synthesis Report. Contribution of Working Groups I, II and III to the Fourth Assessment Report of the Intergovernmental Panel on Climate Change Core Writing Team, Pachauri, R.K. and Reisinger, A. (Eds.) IPCC, Geneva, Switzerland

IPCC. (2014). Climate Change 2014: Impacts, Adaptation, and Vulnerability. Inter-governmental Panel on Climate Change.

IUCN. (2010). Women in REDD critical for climate action. International Union for Conservation of Nature

IUCN. (2011a). IUCN Arborvitae-Forests: a legal challenge. The IUCN Forest Conservation Programme Newsletter, issue 44

IUCN. (2011b). Mainstreaming Gender Considerations in REDD-Plus Policy Implementation in Ghana. International Union for Conservation of Nature

Kanninen, M., Brockhaus, M., Murdiyarso, D. and Nabuurs G. (2010). Harnessing Forests for Climate Change Mitigation through REDD+: challenges and opportunities. Forests and societyresponding to global drivers of change. Vienna, Austria, IUFRO World Series Volume 2, chapter 3, $\mathrm{p}$ 44-45. 
Kajembe, G. C., Silayo, D. S. A., Mwakalobo, A. B. S., and Mutabazi, K. (2013). The Kilosa District REDD+ pilot project, Tanzania. A socioeconomic baseline survey. International Institute for Environment and Development (IIED), London, p 33-34

Kill, J. (2013). Carbon Discredited: Why the EU should steer clear of forest carbon offsets. FERN and Les Amis de la Terre, ISBN: 978-1-906607-30-2

Kissinger, G., Herold, M., and De Sy, V. (2012). Drivers of Deforestation and Forest Degradation: A Synthesis Report for REDD+ Policymakers. Lexeme Consulting, Vancouver Canada

Kula, N., Haines, A., and Fryatt, R. (2013). Reducing Vulnerability to Climate Change in Sub-Saharan Africa: The Need for Better Evidence. PLOS Medicine. Volume 10, Issue 1,

Lang, C. (2013). Launch of No REDD in Africa Network: "REDD could cause genocide". REDD Monitor

Lang, C. (2015). The REDD+ Mechanism will not be enough to curb deforestation in Central Africa: Center for International Forestry Research (CIFOR), REDD Monitor

Larrazabal, A., McCall, M.K., Mwampamba, T. H. and Skutsch, M. (2012). The role of community carbon monitoring for REDD+: A review of experiences. Current Opinion in Environmental Sustainability, $\mathrm{p}$ 707-716.

Larson, A. M., Brockhaus, M., Sunderlin, W. D., Duchelle, A., Babon, A., Dokken, T., Pham, T., Resosudarmo, I. A. P., Selaya, G., Awono, A., \& Huynh, T. B. (2013). Land tenure and REDD+: The good, the bad and the ugly. Global Environmental Change, 23(3), 678-689.

Larson, A. M., Dokken, T., Duchelle, A. E., Atmadja, S., Resosudarmo, I. A. P., Cronkleton, P., Cromberg, M., Sunderlin, W., Awono, A. \& Selaya, G. (2015). The role of women in early REDD+ implementation: lessons for future engagement. International Forestry Review, 17(1), 43-65.

Lawlor, K., Madeira, E. M., Blockhus, J., \& Ganz, D. J. (2013). Community participation and benefits in REDD+: A review of initial outcomes and lessons. Forests, 4(2), 296-318.

Lee, D., Seifert-Granzin, J., Neeff, T., Göhler, D., Liss, B. M and Busch, A. (2011). Maximizing the Cobenefits of REDD-Plus Actions. Discussion paper for a Regional Expert Workshop supported by the German International Climate Initiative, September 27-29 2011, Subic, Philippines.

Leventon, J., Kalaba, F. K., Dyer, J. C., Stringer, L. C. and Dougill, A. J. (2014). Delivering community benefits through REDD+: Lessons from Joint Forest Management in Zambia. Forest Policy and Economics. p 1-2.

Livingston, G. (2015). Opinion: How Women Are Effecting Change in Kenya's Kasigau Corridor. Ecosystem Marketplace-A Forest Trends Initiative

Lohmann, L. (2006). Carbon trading: a critical conversation on climate change, privatisation and power. Development Dialogue no 48. Uppsala: Dag Hammarskjöld Foundation, p 234-238

Madeira, E. C. M. (2008). Policies to Reduce Emissions from Deforestation and Degradation (REDD) in Developing Countries: An examination of the issues facing the incorporation of REDD into market-based climate policies. Resources for the future (RFF).

Madeira, E. M., Kelley, L., Blockhus, J., Ganz, D., Cortez, R., and Fishbein, G. (2012). Sharing the Benefits of REDD+-Lessons from the field. The Nature Conservancy

Metzel, R. (2015). How to translate REDD+ benefit sharing practice into policy. International Union for the Conservation of Nature (IUCN).

Minang, P. A. (2010), Forestry and REDD in Africa, jotoafrika, issue 4.

Minang, P. A., Duguma, L. A., Bernard, F., Mertz, O., and M. Noordwij. (2013). Prospects for agroforestry in REDD+ landscapes in Africa. Elsevier Limited. 1877-3435, p 3-4

Murthy, I. K., Gupta, M., Tomar, S., Munsi, M., Tiwari, R., Hegde, G. T., and Ravindranath, N. H. (2013). Carbon Sequestration Potential of Agroforestry Systems in India. Earth Science and Climate Change- ISSN: 2157-7617

Mutabazi, K. D., George, C. K., Dos Santos, A. S., \& Felister, M. M. (2014). Livelihood implications of REDD+ and costs-benefits of agricultural intensification in REDD+ pilot area of Kilosa, Tanzania. Journal of Ecosystem \& Ecography, 4(2): 144.

Mwangi, E., Meinzen-Dick, R., \& Sun, Y. (2011). Gender and sustainable forest management in East Africa and Latin America. Ecology and Society, 16(1): 17 
Nabanoga, G., Namaalwa, J., and Ssenyonjo, E. (2012). The Ongo Community Forest REDD+ pilot Project, Uganda. A socioeconomic baseline survey. IIED, London, p 21-23

Nakhooda, S., Caravani, A., Bird, N., and Schalatek, L. (2011). Climate finance in Sub-Saharan Africa. Climate finance policy brief. Overseas Development Institute and Heinrich Böll Stiftung North America.

Naoto, J. (2006). International trade and terrestrial open-access renewable resources in a small open economy. Canadian Journal of Economics, Vol. 39, No. 3

Ndobe, S. N. (2010). REDD and Climate Change: Implications for the African Woman. Centre for Environment and Development (CED). Presentation for the REFACOF planning meeting.

Newton, P., Schaap, B., Fournier, M., Cornwall, M., Rosenbach, D. W., DeBoar, J., Whittemore, J., Stock, R., Yoders, M., Brodnig, G., Agrawal, A. (2015). Community forest management and REDD+. Forest Policy and Economics.

Nhantumbo, I. and L. Chiwona-Karltun.(2012). His REDD+, Her REDD: how integrating gender can improve readiness. International Institute for Environment and Development (IIED) Briefing. United Kingdom. IIEC

Norton Rose. (2010). Forest carbon rights in REDD+ countries: a snapshot of Africa. Norton Rose LLP Edition No. NR9190, p 9

OECD. (2017). Building Food Security and Managing Risk in Southeast Asia. OECD Global Forum on Agriculture. OECD Publishing, Paris.

Okali, C. and Naess, L. O. (2013). Making Sense of Gender, Climate Change and Agriculture in subSaharan Africa: Creating Gender-Responsive Climate Adaptation Policy. Future Agricultures Consortium, Working Paper 057

Olivier, J. G. J. (PBL), Janssens-Maenhout, G. (IES-JRC), Muntean, M., (IES-JRC) and Peters, J. A. H. W. (PBL). (2013). Trends in global CO2 emissions: 2013 Report. PBL Netherlands Environmental Assessment Agency, Institute for Environment and Sustainability (IES) of the European Commission's Joint Research Centre (JRC)

Osarogiagbon, R. (2011). REDD and its implication on Community people. A presentation made at Cross River State stakeholders forum on Climate change, REDD and Forest Dependent Community Rights. Nigeria. Environmental Rights Action (ERA)/ Friends of the Earth Nigeria (FOEN).

Pan African Climate Justice Alliance (PACJA). (2012), Carbon trading in Africa. Climate Finance Africa Briefing Paper Series, 3. PACJA and Institute for Security Studies

Parrotta, J. A., C. Wildburger and S. Mansourian. (2012). Understanding Relationships between Biodiversity, Carbon, Forests and People: The Key to Achieving REDD+ Objectives. A Global Assessment Report prepared by the Global Forest Expert Panel on Biodiversity, Forest Management, and REDD+. IUFRO World Series Volume 31, p 16, 54.

Peskett, L. (2011). Benefit sharing in REDD+: exploring the implications for poor and vulnerable people. World Bank and REDD-net. Trust Fund for Environmentally and Socially Sustainable Development (TFESSD)

Poffenberger, M. (2011). Women's micro-finance and forest conservation in India. In IUCN Arborvitae: Attending to gender. The IUCN Forest Conservation Programme Newsletter, issue 43, p 11

Pokorny, B, Scholz, I., and de Jong, W. (2013). REDD+ for the poor or the poor for REDD+? About the limitations of environmental policies in the Amazon and the potential of achieving environmental goals through pro-poor policies. Ecology and Society 18(2): 3.

Population Action International. (2011). Why Population matters to Forests. Population Action International, Washington DC, USA

Population Reference Bureau (PRB). (2013). 2013 World Population Data Sheet. PRB-USAID.

Pye, O. (2012). Carbon Markets and REDD in South-East Asia: An Interview with Chris Lang from REDD Monitor. ASEAS - Austrian Journal of South-East Asian Studies, 5(2), 352-358.

Ribot, J. (2011). Seeing REDD for Local Democracy: A Call for Democracy Standards

Rietbergen-McCracken, J. (2011). EDITOR. Gender in Cancun. In IUCN Arborvitae: Attending to gender. The IUCN Forest Conservation Programme Newsletter, issue 43 
Romero, M. Z., Trærup, S., Wieben, E., Møller, L. R., and Koch, A. (2013). Economics of forest and forest carbon projects- Translating lessons learned into national REDD+ implementation. UNEP Risø Centre-ISBN: 978-87-92706-66-9

Sandbrook, C., Nelson, F., Adams, W. M., and Agrawal, A. (2010). Carbon, forests and the REDD paradox. Fauna and Flora International

Scriven, J. H. N. and Malhi, Y. (2012). Smallholder REDD+ strategies at the forest-farm frontier: a comparative analysis of options from the Peruvian Amazon. Carbon Management 3 (3), future science group, p 265

Setyowati, A. (2012). Ensuring that women benefit from REDD+. Women Organizing for Change in Agriculture and Natural Resource Management (WOCAN), Unasylva 239, Vol. 63

Shames, J. (2013). How can small-scale farmers benefit from carbon markets? CCAFS Policy Brief no. 8. CGIAR Research Program on Climate Change, Agriculture and Food Security (CCAFS). Copenhagen, Denmark

Shanahan, M., Shubert, W., Scherer, C., Corcoran. T. (2013). Climate Change in Africa: A Guidebook for Journalists. United Nations Educational, Scientific and Cultural Organization (UNESCO) Series on Journalism Education, France

Sills, E. O., Atmadja, S. S., de Sassi, C., Duchelle, A. E., Kweka, D. L., Resosudarmo, I. A. P., \& Sunderlin, W. D. (Eds.). (2014). REDD+ on the ground: A case book of subnational initiatives across the globe. Bogor, Indonesia: CIFOR. https://www.cifor.org/library/5202/redd-on-the-ground-acase-book-of-subnational-initiatives-across-the-globe/

Smith, H. (2011). REDD+ in East Africa: The gender dimension of the Readiness Plans in Uganda, Kenya and Tanzania. University of California, San Diego

Spratt, S. (2016). Forest taxation and REDD+. Institute of Development Studies, University of Sussex. ICTD Annual Meeting, 10-13 February 2016. Addis Ababa.

Streck, C. (2010). An African Agricultural Carbon Facility, Ford Foundation

The Forests Dialogue (TFD). (2008). Beyond REDD: The Role of Forests in Climate Change. The Forests Dialogue, USA

UNDP. (1995). Human Development Report, 1995. New York, USA

UNFCCC. (2007a). Climate Change: Impacts, Vulnerabilities and Adaptation in Developing Countries. Climate Change Secretariat (UNFCCC), Bonn, Germany

UNFCCC. (2007b). Investment and Financial Flows to Address Climate Change. United Nations Framework Convention on Climate Change, Bonn, Germany.

UNFCCC, (2010). Decision 1/CP.16 The Cancun Agreements: Outcome of the Work of the Ad Hoc Working Group on Long-term Co-operative Action under the Convention. In: UNFCCC (Ed.), (UNFCCC/CP/2010/7).

UN-REDD. (2013). Guidance Note on Gender Sensitive REDD+. United Nations REDD Programme UN-REDD. (2016). UN-REDD Programme. Retrieved: July, 14, 2016 from: http://www.un-redd.org/ UN WomenWatch. (2009). Women, Gender Equality and Climate Change. Retrieved: September, 6, 2016 from http://www.un.org/womenwatch/feature/climate_change/.

USAID. (2017). Greenhouse Gas Emissions in Indonesia. United States Agency for International Development (USAID).

Virgilio, N. and Marshall, S. (2009). Forest Carbon Strategies in Climate Change Mitigation: Confronting Challenges Through On-the- Ground Experience. The Nature Conservancy. Arlington, Virginia.

Virgilio, N. R., Marshall, S., Zerbock, O., and Holmes, C. (2010). Reducing Emissions from Deforestation and Degradation (REDD): A Casebook of On-the-Ground Experience. The Nature Conservancy, Conservation International and Wildlife Conservation Society. Arlington, Virginia.

Wambugu, S. W. Chomba, S. W. and Atela, J. (2015). Institutional arrangements for climate-smart landscapes. In Minang, P. A., van Noordwijk, M., Freeman, O. E., Mbow, C., de Leeuw, J., \& Catacutan, D. (Eds.) Climate-Smart Landscapes: Multi-functionality in Practice, 257-273. Nairobi, Kenya: World Agroforestry Centre (ICRAF). 
Wertz-Kanounniko, S. and Kongphan-Apirak, M.(2008). Reducing forest emissions in Southeast Asia: A review of drivers of land-use change and how payments for environmental services (PES) schemes can affect them. Center for International Forestry Research (CIFOR). Working Paper No. 41 p 5-6, 13.

WFSE-IUFRO. (2009). Making Sub-Saharan African Forests Work for People and Nature: Policy approaches in a changing global environment. Special Project on World Forests, Society and Environment (WFSE) of the International Union of Forest Research Organizations (IUFRO).

WOCAN. (2011). Getting REDD+ Right for Women: An analysis of the barriers and opportunities for women's participation in the REDD+ sector in Asia. Prepared by Women Organizing for Change in Agriculture and Natural Resource Management (WOCAN) and the United States Forest Service and produced by the United States Agency for International Development (USAID), $p$ 19.

WOCAN, UN-REDD and USAID. (2013). Women's Inclusion in REDD+ in Cambodia: Lessons from Good Practices in Forest, Agriculture and Other Natural Resources Management Sectors. Joint Regional Initiative for Women's Inclusion in REDD+. Women Organizing for Change in Agriculture and Natural Resource Management (WOCAN), the United Nations Collaborative Programme on Reducing Emissions from Deforestation and Forest Degradation (UN-REDD) and the United States Agency for International Development (USAID).

World Bank Africa. (2017). Forests in Sub-Saharan Africa: Challenges and Opportunities. PROFOR Innovation and Action for Forests. World Bank Africa Region. 